\title{
UITALIOLNT STDELLLTIOI
}

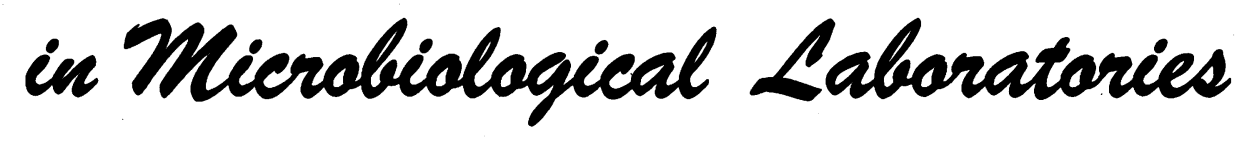

\begin{abstract}
A discussion of the germicidal protection offered by ultraviolet lamps installed in airlocks, at doorways, and on ceilings of microbiological laboratories and walk-in incubators.
\end{abstract}

By ARNOLD G. WEDUM, M.D., EVERETT HANEL, Jr., B.S., and G. BRIGGS PHILLIPS, B.S.

$\mathrm{U}$ LTRAVIOLET radiation has been used for a number of years in some infectious disease laboratories to provide barriers between hazardous and safe areas and to reduce bacterial contamination.

The decision, by the authors, to recommend installation of ultraviolet lamps in airlocks, in doorways, and on ceilings of selected laboratories and walk-in incubators was made after experiments showed that ultraviolet radiation could be used to separate areas of unequal infectious risk.

Earlier reports dealt with ultraviolet radiation for sterilizing small volumes of bacterially contaminated air and for treating single sheets of paper passed from infectious areas $(1,2)$.

Dr. Wedum is safety director, Fort Detrick, Army Chemical Corps, Frederick, Md. Mr. Hanel is chief of the Agent Control Branch, Safety Division, Fort Detrick, and Mr. Phillips is a bacteriologist with the Safety Division. This report is one in a series.
Wedum (3) also mentioned the use of ultraviolet racks for cages housing infected animals.

\section{Experimental Methods}

Cultures of Serratia indica were used in most of our studies. In some tests, normal bacterial flora of the air or surface contaminants-were used as indicators of germicidal effectiveness. Aerosols of $S$. indica were produced from 24hour broth cultures by a DeVilbiss No. 40 nebulizer.

To evaluate the effectiveness of ultraviolet (UV) installations, air was sampled for bacterial content by sieve air samplers (4) with the UV lamps off and on. In some instances liquid impinger samplers were used for the UVoff air samples. The comparative number of organisms recovered and the percent reduction allowed an estimation of the effectiveness of the germicidal radiation.

During these studies some attention was given to the phenomenon of photoreactivation, first described by Kelner (5). Recovery plates 
were sometimes prepared in duplicate and incubated under white light and in the dark. However, our experiments called for lethal concentrations of ultraviolet radiation and were performed during the day when generous amounts of white light were present before and during the tests, and no photoreactivation was demonstrated. The average relative humidity in the laboratories during these studies was 56 percent.

\section{Airlocks}

In this paper an airlock is defined as a small empty room with a door at each end, constructed to create a dead airspace for a safer passageway between two areas. Germicidal lamps were installed on the ceiling of a variety of such rooms and experiments were conducted to determine the effectiveness of ultraviolet radiation in preventing the passage of airborne micro-organisms from area to area.

Tests conducted with one typical airlock illustrate the effect of germicidal radiant energy. Three 30-watt UV lamps were installed on the ceiling in an airlock 8 feet long, $3 \frac{1}{2}$ feet wide and 10 feet high. Movement of air between the rooms separated by this airlock was controlled during testing by means of exhaust fans, although in practice the room of greater infectious hazard is kept at a negative pressure.

A meter employing a WL-775 Tantalum photocell and calibrated for response at wave. length $2537 \mathrm{~A}$ was used to determine the radiant intensities of energy throughout the airlock. All measurements were taken on a horizontal

Table 1. Ultraviolet intensities in an $8^{\prime} \times 3^{\prime} \frac{1}{2}^{\prime} \times 10^{\prime}$ airlock equipped with three 30 -watt lamps

\begin{tabular}{|c|c|c|c|c|c|c|c|}
\hline \multirow{3}{*}{ Distance from floor level (inches) } & \multicolumn{7}{|c|}{ Microwatts per square centimeter } \\
\hline & \multicolumn{7}{|c|}{ Distance in feet from north to south end } \\
\hline & 1 & 2 & 3 & 4 & 3 & 2 & 1 \\
\hline 60 & $\begin{array}{r}10 \\
33 \\
52 \\
81 \\
157\end{array}$ & $\begin{array}{r}38 \\
43 \\
56 \\
81 \\
118\end{array}$ & $\begin{array}{r}43 \\
44 \\
57 \\
80 \\
115\end{array}$ & $\begin{array}{r}44 \\
49 \\
59 \\
75 \\
147\end{array}$ & $\begin{array}{r}41 \\
50 \\
59 \\
75 \\
112\end{array}$ & $\begin{array}{r}40 \\
48 \\
59 \\
74 \\
110\end{array}$ & $\begin{array}{r}33 \\
46 \\
54 \\
85 \\
144\end{array}$ \\
\hline
\end{tabular}

Table 2. Bacteriological tests of an ultraviolet airlock using Serratia indica as the test organism

\begin{tabular}{|c|c|c|c|c|c|c|}
\hline \multirow{3}{*}{ Test number } & \multirow{3}{*}{$\begin{array}{l}\text { Air veloc- } \\
\text { ity, feet } \\
\text { per second }\end{array}$} & \multirow{3}{*}{$\begin{array}{l}\text { Position } \\
\text { of airlock } \\
\text { doors }\end{array}$} & \multicolumn{3}{|c|}{$\begin{array}{l}\text { Cloud concentration per } \\
\text { cubic foot of air }\end{array}$} & \multirow{3}{*}{$\begin{array}{l}\text { Percent } \\
\text { reduction } \\
\text { of S. indica }\end{array}$} \\
\hline & & & \multirow{2}{*}{$\begin{array}{l}\text { At neb- } \\
\text { ulizing } \\
\text { position }\end{array}$} & \multicolumn{2}{|c|}{$\begin{array}{c}\text { At collection } \\
\text { point past the } \\
\text { airlock }\end{array}$} & \\
\hline & & & & UV on & UV off & \\
\hline 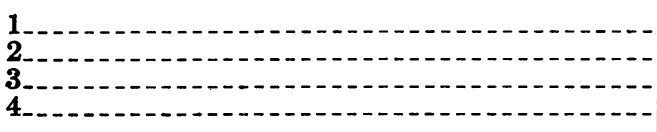 & $\begin{array}{r}2 \\
2 \\
2\end{array}$ & $\begin{array}{l}\text { open } \\
\text { open } \\
\text { open.-.-- } \\
\text { olosed.-- }\end{array}$ & $\begin{array}{r}408 \\
938 \\
3,347 \\
110,600\end{array}$ & $\begin{array}{l}0.4 \\
0 \\
0.8 \\
14\end{array}$ & \begin{tabular}{|r}
43 \\
81 \\
334 \\
211,600
\end{tabular} & $\begin{array}{r}99 \\
100 \\
99 \\
99\end{array}$ \\
\hline
\end{tabular}

1 Leakage around door.

2 Estimated.

Note: No S. indica appeared in control air samples taken before each test. Organisms passing through the airlock were collected with sieve samplers for 5 minutes at $1 \mathrm{cfm}$. Liquid impingers were used to determine the number of organisms per cubic foot of air at the point of nebulization. The collection efficiency of the samplers is estimated at 95 percent for the liquid impinger and $\mathbf{4 5}$ to 70 percent for the sieve sampler. 
Ultraviolet lamp installation at doorway.

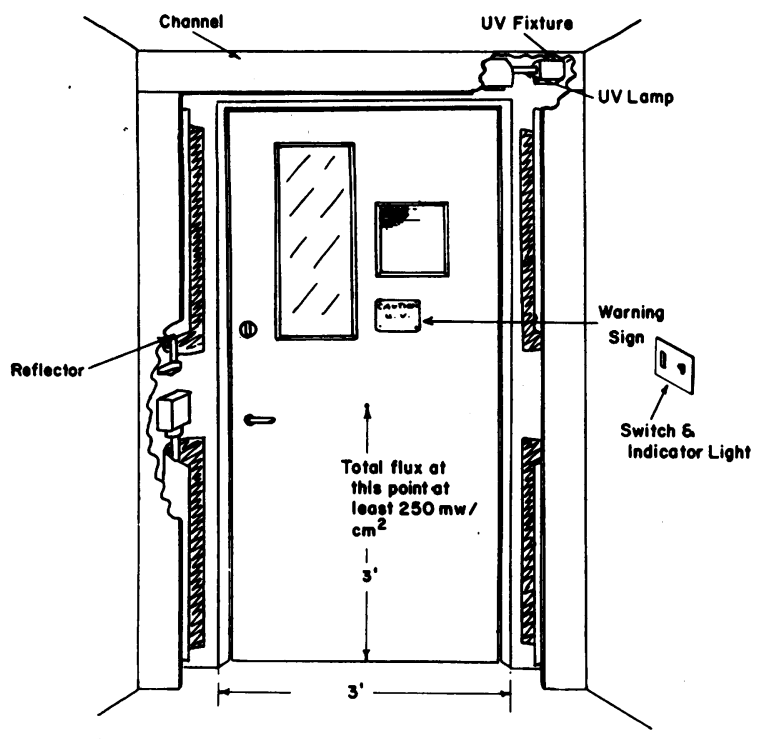

plane, and the radiation measured represented energy received from above. With the exception of one reading, all areas received at least 30 microwatts per sq. cm. (table 1 ).

Bacteriological tests were conducted with the doors open and closed. Aerosols of S. indica were produced outside the airlock on the upwind side, and samples were taken outside the airlock on the downwind side. The bacterial aerosol concentration was controlled by nebulizing a culture that had been diluted to the desired concentration. Generation of the aerosol continued throughout each test. The results show at least a 99 -percent reduction of the bacterial aerosol in every case (table 2). Our experience with a variety of similarly radiated airlocks has shown that few, if any, airborne vegetative bacteria or bacteriophage particles will penetrate such a barrier if air velocities of about 2 feet per second are involved and if the number of UV lamps attached to the ceiling provide a floor intensity of 20 to 30 microwatts per sq. $\mathrm{cm}$.

\section{Doorway Barriers}

In the absence of an airlock, an effective barrier can be made by providing a radiation screen across a doorway. A design we recommend for this purpose uses five 17-watt cold cathode UV lamps with aluminum reflectors placed in a wood or metal channel built around the door- way (see drawing). The channel is placed so that the door opens away from the barrier. In this manner a screen of high intensity ultraviolet radiation is projected across the doorway.

Typical ultraviolet intensities obtained with a door barrier are shown in table 3. Intensity measurements in microwatts per square centimeter from three directions have been added and arbitrarily designated as the "total energy flux."

For bacteriological testing of the typical UV door barrier, cultures of $S$. indica were nebulized either on the upwind or downwind side of the barrier while sieve air samplers were operated on the opposite side. Two conditions were included which reversed momentarily the normal airflow pattern. For example, the pumping action of another door in the room on the positive pressure side (upwind, clean side) would pull airborne organisms from the contaminated room through the barrier door. Similarly, the opening of the barrier door momentarily destroyed the pressure balance and airborne organisms entered the positive pressure clean area.

The results of these experiments are summarized in table 4. In brief, if the total energy flux (table 3 ) is at least 250 microwatts per sq. $\mathrm{cm}$. at the midpoint in the barrier (see drawing) the ultraviolet radiation will provide significant germicidal action.

\section{Laboratory Ceilings}

Unshielded UV lamps can be installed on the laboratory ceiling to provide germicidal treat-

Table 3. Ultraviolet intensities in microwatts per square centimeter at the vertical middle of a door barrier

\begin{tabular}{c|r|r|r|r}
\hline $\begin{array}{c}\text { Feet } \\
\text { above the } \\
\text { floor }\end{array}$ & $\begin{array}{c}\text { Radia- } \\
\text { tion } \\
\text { from } \\
\text { above }\end{array}$ & $\begin{array}{c}\text { Radia- } \\
\text { tion } \\
\text { from } \\
\text { left }\end{array}$ & $\begin{array}{c}\text { Radia- } \\
\text { tion } \\
\text { from } \\
\text { right }\end{array}$ & $\begin{array}{c}\text { Total } \\
\text { energy } \\
\text { fux } \\
\text { received }\end{array}$ \\
\hline & - & - & - & - \\
\hline 5 & 166 & 142 & 144 & 452 \\
\hline 3 & 96 & 126 & 126 & 348 \\
\hline 2 & 113 & 110 & 289 \\
\hline & 52 & 126 & 144 & 322 \\
\hline
\end{tabular}


ment of the air and exposed surfaces during periods when the room is unoccupied. Lamps can also be turned on in case of accidental spillage of infectious materials and just before or during pouring of sterile media. We recommend that ceiling lamps be located to provide an intensity of 5 to 10 microwatts per sq. $\mathrm{cm}$. on exposed floor surfaces.

Experiments were conducted in four rooms to determine the reduction in normal airborne bacteria when two 30-watt UV lamps, attached on the ceiling of each room, were turned on for 1 hour. Doors and windows of the rooms were closed and activity held to a minimum during the experiments. Air in the room was sampled for bacterial content with sieve samplers before, during, and after the 1-hour ultraviolet treatment. Samples were taken at the tabletop level with each sampler shielded from direct radiation. The experiment was repeated three times in each laboratory; the averaged results are shown in table 5.

One hour irradiation resulted in an 86-percent decrease in normal airborne bacteria. Common spore-forming bacteria were predominant in the UV-on samples. The number of airborne bacteria increased shortly after the lamps were turned off.

\section{Walk-In Incubators}

Conditions in walk-in incubators are generally favorable for the survival or growth of contaminating micro-organisms. Since incubators usually are not ventilated, the microbial population may be quite high. When infectious cultures are incubated, escape of pathogens from broken flasks or from flasks with missing stoppers may constitute a hazard to persons entering the incubator. Breakage or spillage on a shaking machine or from a culture aeration apparatus may be especially dangerous.

Evaluation studies were made of the effectiveness of ultraviolet radiations in reducing surface and airborne microbial flora in a $9 \times 8$ foot walk-in incubator room with an 8-foot ceiling. Triplicate samples of air and surfaces in the room $\left(30^{\circ} \mathrm{C}\right.$.) were taken for 6 days under three separate conditions and examined for common bacteria and fungi. The conditions were :

1. Control-no ultraviolet.

2. Indirect ultraviolet-one 17-watt cold cathode UV lamp mounted 8 inches below the ceiling in the center of the room and shielded to irradiate upwards.

3. Indirect and direct ultraviolet-condition (2) plus one 17-watt lamp mounted 12 inches below the ceiling and irradiating downward.

With indirect ultraviolet, radiation of from 8 to 35 microwatts per sq. $\mathrm{cm}$. (due mostly to reflectance) was present on the upper shelves in the room, but no radiation reached the floor. When both lamps were burning, 17 to 82 microwatts per sq. cm. of radiant energy was present on the shelves, and the exposed floor area re-

Table 4. Bacteriological tests of an ultraviolet door barrier

\begin{tabular}{|c|c|c|c|c|c|c|}
\hline \multirow{3}{*}{ Test conditions } & \multirow{3}{*}{$\begin{array}{l}\text { Point of nebulization } \\
\text { of Serratia indica }\end{array}$} & \multirow{3}{*}{$\begin{array}{l}\text { Position of sieve } \\
\text { samplers }\end{array}$} & \multicolumn{3}{|c|}{$\begin{array}{l}\text { Cloud concentration per } \\
\text { cubic foot of air }\end{array}$} & \multirow{3}{*}{$\begin{array}{c}\text { Percent } \\
\text { efficiency } \\
\text { of UV } \\
\text { door } \\
\text { barrier }\end{array}$} \\
\hline & & & \multirow{2}{*}{$\begin{array}{c}\text { At neb- } \\
\text { ulizing } \\
\text { point }\end{array}$} & \multicolumn{2}{|c|}{$\begin{array}{l}\text { At collection point } \\
\text { by sieve samplers }\end{array}$} & \\
\hline & & & & UV on & UV off & \\
\hline Hall door closed & Positive pressure & Negative pressure & 40 & 0 & 5. 4 & 100 \\
\hline $\begin{array}{l}\text { Outside door opened } 10 \\
\text { times. }\end{array}$ & $\begin{array}{l}\text { Negative pressure } \\
\text { side. }\end{array}$ & $\begin{array}{l}\text { Positive pressure } \\
\text { side. }\end{array}$ & & 0.2 & 58 & 99. 7 \\
\hline $\begin{array}{l}\text { Two entrances and two } \\
\text { exits by man. }\end{array}$ & Negative pressure & $\begin{array}{l}\text { Positive pressure } \\
\text { side. }\end{array}$ & 214,000 & 13. 2 & 178 & 92.5 \\
\hline
\end{tabular}

Note: No S. indica appeared in control air samples taken before each test. Organisms passing through the barrier were collected with sieve samplers for 5 minutes at $1 \mathrm{cfm}$. Liquid impingers were used to determine the number of organisms per cubic foot of air at the point of nebulization. The collection efficiency of these samplers is estimated at 95 percent for the liquid impinger and 45 to 70 percent for the sieve sampler. 
Table 5. Reduction of airborne bacteria by ultraviolet radiation in four test rooms

\begin{tabular}{|c|c|c|c|c|c|c|c|c|c|c|}
\hline \multirow{3}{*}{ Room number } & \multirow{3}{*}{$\begin{array}{l}\text { Cubic } \\
\text { feet } \\
\text { in } \\
\text { room }\end{array}$} & \multirow{3}{*}{$\begin{array}{c}\text { Average } \\
\text { bacterial } \\
\text { count per } \\
\text { cubic foot } \\
\text { of air } \\
\text { before } \\
\text { lamps } \\
\text { were on }\end{array}$} & \multicolumn{6}{|c|}{ Lamps on 1 hour } & \multirow{3}{*}{$\begin{array}{c}\text { 1st } 20 \\
\text { minutes } \\
\text { bacteria } \\
\text { per } \\
\text { cubic } \\
\text { foot }\end{array}$} & \multirow{3}{*}{$\begin{array}{c}2 \mathrm{~d} 20 \\
\text { minutes } \\
\text { bacteria } \\
\text { per } \\
\text { cubic } \\
\text { foot }\end{array}$} \\
\hline & & & \multicolumn{2}{|c|}{1 st 20 minutes } & \multicolumn{2}{|c|}{$2 \mathrm{~d} 20$ minutes } & \multicolumn{2}{|c|}{$3 \mathrm{~d} 20$ minutes } & & \\
\hline & & & $\begin{array}{l}\text { Count } \\
\text { per } \\
\text { cubic } \\
\text { foot }\end{array}$ & $\begin{array}{l}\text { Percent } \\
\text { reduc- } \\
\text { tion }\end{array}$ & $\begin{array}{l}\text { Count } \\
\text { per } \\
\text { cubic } \\
\text { foot }\end{array}$ & $\begin{array}{l}\text { Percent } \\
\text { reduc- } \\
\text { tion }\end{array}$ & $\begin{array}{l}\text { Count } \\
\text { per } \\
\text { cubic } \\
\text { foot }\end{array}$ & $\begin{array}{l}\text { Percent } \\
\text { reduc- } \\
\text { tion }\end{array}$ & & \\
\hline $\begin{array}{l}1 \\
\mathbf{2} \\
\mathbf{3} \\
4\end{array}$ & $\begin{array}{r}1,900 \\
1,900 \\
375 \\
1,900\end{array}$ & $\begin{array}{l}13.6 \\
17.7 \\
33.0 \\
13.6\end{array}$ & $\begin{array}{r}4.6 \\
10.4 \\
4.4 \\
3.2\end{array}$ & $\begin{array}{l}66.0 \\
40.0 \\
87.0 \\
75.5\end{array}$ & $\begin{array}{l}4.5 \\
7.4 \\
2.5 \\
2.1\end{array}$ & $\begin{array}{l}67.0 \\
58.0 \\
92.5 \\
84.5\end{array}$ & $\begin{array}{l}\text { 1. } 9 \\
\text { 4. } 4 \\
2.7 \\
\text { 1. } 7\end{array}$ & $\begin{array}{l}86.0 \\
75.0 \\
91.8 \\
87.5\end{array}$ & $\begin{array}{l}\text { 4. } 1 \\
\text { 7. } 4 \\
\text { 4. } 2 \\
\text { 4. } 7 .\end{array}$ & $\begin{array}{r}5.3 \\
11.0 \\
6.6 \\
6.9\end{array}$ \\
\hline Averages . . . & $\ldots$ & 19. 47 & 5. 65 & 71.0 & 4. 1 & 79.0 & 2. 7 & 86. 0 & 5. 1 & 7. 45 \\
\hline
\end{tabular}

ceived approximately 13 microwatts per sq. $\mathrm{cm}$.

During the 6-day test for each condition, normal use of the incubator was continued. The bacteria and fungi recoverable from the air by sieve samplers and from the walls by moistened sterile swabs during the test periods were reduced by 83 to 100 percent as compared to the controls (table 6). Indirect UV radiation reduced the number of micro-organisms on the floor only slightly. Direct radiation caused an 86.5-percent reduction in floor bacteria on exposed surfaces, but the reduction in numbers of fungi was not determined because of overgrowth by bacteria in the control samples.

Obviously, when ultraviolet is used, the microbial population is reduced and then remains

Table 6. Reduction of organisms by continuous ultraviolet in an incubator room $\left(30^{\circ} \mathrm{C}.\right)$

\begin{tabular}{|c|c|c|c|c|}
\hline \multirow{3}{*}{ Condition tested } & \multicolumn{4}{|c|}{$\begin{array}{c}\text { Percent reduction by } \\
\text { ultraviolet } 1\end{array}$} \\
\hline & \multicolumn{2}{|c|}{$\begin{array}{l}\text { Indirect } \\
\text { ultraviolet }\end{array}$} & \multicolumn{2}{|c|}{$\begin{array}{l}\text { Direct and } \\
\text { indirect } \\
\text { ultraviolet }\end{array}$} \\
\hline & $\begin{array}{l}\text { Bac- } \\
\text { teria }\end{array}$ & Fungi & $\begin{array}{l}\text { Bac- } \\
\text { teria }\end{array}$ & Fungi \\
\hline $\begin{array}{l}\text { Airborne organisms } \\
\text { Organisms on the floor } \\
\text { Organisms on the walls } \\
\text { - }\end{array}$ & $\begin{array}{l}83.4 \\
(2) \\
99.4\end{array}$ & $\begin{array}{l}84.7 \\
(2) \\
92.0\end{array}$ & $\begin{array}{l}91.8 \\
86.5 \\
100\end{array}$ & $\begin{array}{l}84.7 \\
(3) \\
100\end{array}$ \\
\hline
\end{tabular}

1 Averaged from samples in triplicate taken on each of 6 days.

2 Very little reduction.

3 Reduction not determined. rather constant. Equilibrium conditions were maintained although normal use of the incubator continued. When indirect UV was used, all air samples were taken close to the floor where no radiation was present. Air circulation was therefore responsible for lower air counts in all parts of the incubator. Of course, no decontamination occurred on surfaces not exposed to radiation.

The reduction of fungi was about the same as for bacteria, in spite of the fact that molds are considered to be 100 to 1,000 times as resistant as bacteria (6). This parallelism suggests that the exposure times used were sufficient to kill even the hardiest micro-organisms, and, in reality, the limiting factor for destruction was the ability or inability of the radiation to reach the cells.

In an additional series of tests, when $4 \mathrm{ml}$. of an $S$. indica culture $\left(2 \times 10^{7}\right.$ cells per ml.) were nebulized in the incubator, all airborne cells were eliminated in 1 minute by direct and indirect radiation and in 10 minutes by indirect radiation alone. With the UV lamps off, $S$. indica was recovered for 1 hour.

In unreported studies, in which agar plates inoculated with Brucella abortus, strain A-19, or $S$. indica were placed in a walk-in incubator room equipped with UV lamps, we have observed that those agar plates placed 3 feet or closer to the lamps must be shielded continuously from the radiations to prevent inhibition of colony growth. Since $2537 \mathrm{~A}$ radiations will not penetrate ordinary glassware, colony inhibition at distances shorter than 3 feet is 
presumably due to the longer wavelengths emitted by the lamps. Ultraviolet radiation is not recommended for incubators if it is critically important to preserve the genetic or nutritional characteristics of the micro-organisms in use.

\section{Safety Measures}

Skin or eye protection is not usually required for persons walking through ultraviolet barriers. Protection is required, however, for persons exposed to the radiation for longer than a few seconds. Personnel must be trained not to look at the UV lamps and not to loiter in an irradiated area. We recommend that warning signs and small blue indicator lights and switches be placed at each installation.

A regular maintenance program for lamp testing and cleaning is necessary. Lamps should be turned off and wiped with a soft cloth wet with alcohol. The frequency of cleaning will vary according to the conditions, but in any case the interval between cleaning should not be greater than 2 weeks. Of course, good training and good laboratory housekeeping is of prime importance in preventing the escape of harmful organisms from infectious disease laboratories.

\section{Conclusion}

Ultraviolet radiation can be used around doorways and in airlocks to separate areas of unequal infectious risk and to reduce the number of infectious micro-organisms and general contaminants in laboratories and in walk-in incubators.

\section{REFERENCES}

(1) Miller, O. T., Schmitt, R. F., and Phillips, G. B.: Applications of germicidal ultraviolet in infectious disease laboratories. I. Sterilization of small volumes of air by ultraviolet irradiation. Am. J. Pub. Health 45:1420-1423, November 1955.

(2) Phillips, G. B., and Novak, F. E. : Applications of germicidal ultraviolet in infectious disease laboratories. II. An ultraviolet pass-through chamber for disinfecting single sheets of paper. Appl. Microbiol., vol. 4, 1956 . In press.

(3) Wedum, A. G.: Bacteriological safety. Am. J. Pub. Health 43: 1428-1437, November 1953.

(4) DuBuy, H. G., and Crisp, R. L.: A sieve device for sampling air-borne micro-organisms. Pub. Health Rep. 59: 832, June 30, 1944.

(5) Kelner, A.: Photoreactivation of ultraviolet irradiated Escherichia coli with special reference to the dose-reduction principle and to ultraviolet induced mutation. J. Bacteriol. 58:511-522, October 1949.

(6) Koller, L. R.: Ultraviolet radiation. New York, John Wiley and Sons, Inc., 1952.

\section{Methodology Research Award}

Nominations for the Fifth Kimble Methodology Research Award are being accepted until June 1, 1956. This award is given in recognition of scientific investigations affecting public health laboratory techniques.

For rules governing nominations and information on nomination procedures, write to Dr. Thomas S. Hosty, chairman, Nominating Committee, Kimble Award, Bureau of Laboratories, Alabama State Department of Health, Montgomery 4, Ala. 